
\title{
ЭВОЛЮЦИЯ ИНСТИТУТА УСЛОВНО-ДОСРОЧНОГО ОСВОБОЖДЕНИЯ ОТ ОТБЫВАНИЯ НАКАЗАНИЯ В РОССИИ
}

\section{EVOLUTION OF THE INSTITUTION OF PAROLE FROM SERVING A SENTENCE IN RUSSIA}

\section{G. Toskina}

Summary: This article explores the question of the evolution of the institution of parole from serving a sentence in Russia in different historical periods. The author of the article comes to the opinion that, despite the long period of existence in the Russian system of legislation, repeated modernization, contradictory practice of application, to date, in the full sense of an effective institution of parole from serving a sentence has not been created. There is still subjectivity in the courts' satisfaction of applications for conditional early release from serving a sentence, which indicates both the inaccuracy of the lawmaker's formulation of the grounds for its application, and historical traditions that prevent legislating the optimal list of grounds for conditional early release from serving a sentence and thus ensure uniform law enforcement practice on parole.

Keywords: parole from serving a sentence, history of criminal legislation, criminal code of the Russian Federation, convicts, applications for parole from serving a sentence.
$\mathrm{B}$ современный период внимание к проблемам института условно-досрочного освобождения от отбывания наказания, несмотря на его значительный период существования в российской системе законодательства, неоднократную модернизацию, длительную практику его применения в истории России, остается на высоком уровне.

Президиум Верховного Суда Российской Федерации, осуществляющий анализы судебной практики уголовных дел, по которым осужденные ходатайствовали об условно-досрочном освобождении от отбывания наказания, в 2014 году подготовил Обзор, в котором была представлена практика рассмотрения российскими судами материалов законченных в 2013 году дел по условно-досрочному освобождению от отбывания наказания. Предыдущий обзор данной судебной инстанцией проводился в 2009 г. Даже беглый анализ этого Обзора, а также статистики дел об условно-досрочном освобождении, позволяет сделать вывод о том, что в данный период шло сокращение и рассмотренных, и удовлетворенных ходатайств об условно-досрочном освобождении от отбывания наказания в 2010-2013 гг. Это, отчасти, также свидетельствует о сложности применения норм уголов-
Тоскина Галина Николаевна

к.ю.н., доцент, ФГБОУ ВО «Ульяновский государственный университет» o-genia@yandex.ru

Аннотация: В данной статье исследуется вопрос об особенностях эволюции института условно-досрочного освобождения от отбывания наказания в России в различные исторические периоды. Автор статьи приходит к мнению, что, несмотря на длительный период существования в российской системе законодательства, неоднократную модернизацию, противоречивую практику применения, до настоящего времени в полном смысле эффективного института условно-досрочного освобождения от отбывания наказания не создано. Сохраняется субъективизм в удовлетворении судами ходатайств 0 условно-досрочном освобождении от отбывания наказания, что свидетельствует как о неточности формулирования законодателем оснований для его применения, так и 06 исторических традициях, мешающих законодательно закрепить оптимальный перечень оснований для условно-досрочного освобождения от отбывания наказания и тем самым обеспечить единообразную правоприменительную практику по условно-досрочному освобождению.

Ключевые слова: условно-досрочное освобождение от отбывания наказания, история уголовного законодательства, Уголовный кодекс Российской Федерации, осужденные, ходатайства об условно-досрочном освобождении от отбывания наказания.

ного законодательства о условно-досрочном освобождении от отбывания наказания, опираясь на которые суды по схожим случаям осужденных выносят разные решения, в одних - удовлетворяя, в других отказывая в удовлетворении ходатайств о условно-досрочном освобождении от отбывания наказания.

Для повышения единообразия практики в этой области правоотношений в современный период были приняты ряд мер (в ст. 79 Уголовного кодекса Российской Федерации «Условно-досрочное освобождение от отбывания наказания» изменения вносились более 10 раз, а в Постановлении Пленума Верховного Суда от 21 апреля 2009 г. № 8 - более трех раз), но и они до настоящего времени не повлекли полной оптимизации института условно-досрочного освобождения от отбывания наказания (далее, в т.ч. - УДО), возможно в силу исторических традиций в регулировании его норм и практики их применения, а возможно и ввиду сомнений в эффективности норм об УДО, связанных с оценкой целесообразности исполнения уголовного наказания.

Очевидно, что, несмотря на длительное историческое развитие института УДО и его неоднократную мо- 
дернизацию в рамках уголовного, уголовно-процессуального и уголовно-исполнительного права, он остается «динамично развивающимся» межотраслевым правовым институтом.

В институте УДО, даже после последних изменений в российское законодательство, значительно ужесточивших применение механизма УДО, остаются проблемы. Они связаны с тем, что на практике не во всех случаях получается достичь целей УдО и обеспечить исправление осужденных, их стабильное законопослушное поведение. Это во многом связано с проблемами несовершенства норм уголовного закона, определяющего виды обязанностей, которые суд налагает на осужденного по УДО, порядок применения УДО, его действия на осужденных к пожизненному лишению свободы, иным категориям осужденных, с проблемами отсутствия единообразного подхода к признанию судами осуждённого утратившим общественную опасность и не нуждающимся в дальнейшем отбывании наказания.

С другой стороны, институт УДО в правовой науке выступает значимой для разработки проблематикой, так как ученые до настоящего времени ведут споры о юридической природе УДО, реализуемой в российском законодательстве концепции УдО, возможности заимствования в России опыта реализации УдО в зарубежных странах, основании УДО, расширении и закреплении в уголовном законе основного и дополнительного, открытого или закрытого перечня обязанностей, налагаемых на осужденного по УДО, и т.д.

Все эти сложности правоприменительного, правотворческого и теоретического характера в институте УДО, проблемы его законодательной регламентации применения отражают сложности его становления еще в дореволюционный и советский периоды развития уголовного законодательства.

Институт условно-досрочного освобождения от отбывания наказания был известен еще на Руси в XIII в. Начиная с Александра Невского, стала распространяться практика освобождения от наказания иностранных осужденных воинов.

Однако институт условно-досрочного освобождения от отбывания наказания как совокупность уголовноправовых, уголовно-процессуальных, уголовно-исполнительных правовых норм, регулирующих основания применения, круг наказаний, в рамках которых существует возможность применения условно-досрочного освобождения, основания применения и отмены УдО от отбывания наказания получил широкую практику применения в Российской империи только в начале XIX в. через Попечительное о тюрьмах общество, а затем только законодательное закрепление во второй половине XIXв.
В Законе от 5 декабря 1866 г. «Об учреждении приютов и колоний для нравственного исправления несовершеннолетних преступников» содержалась норма о том, что к несовершеннолетним лицам может быть применено условно-досрочное освобождение от отбывания наказания, если ими уже проведено 2/3 времени с хорошим поведением в приюте по отбыванию наказания (ст. 10).

Важно, что в Российской империи был издан первый специальный нормативный правовой акт об условнодосрочном освобождении - Закон от 22 июня 1909 г. «Об условно-досрочном освобождении», расширивший субъективный состав своего правового регулирования и на совершеннолетних осужденных. Также в этом источнике системы дореволюционного уголовного законодательства закреплялось само понятие условно-досрочного освобождения.

В советский период развития уголовного законодательства развитие института условно-досрочного освобождения от отбывания наказания продолжилось. Практически в каждом источнике уголовного законодательства данного периода содержались нормы об Удо. Это, прежде всего:

- Декрет от 7 марта 1918 г. «О суде», предусматривавший условную и безусловную формы условнодосрочного освобождения;

- Постановление Наркомата юстиции РСФСР от 25 ноября 1918 г., утвердившее инструкцию о досрочном освобождении, в том числе по ходатайству близких осужденного;

- Постановление Народного комиссариата юстиции от августа 1920 г., внесшее изменения в инструкцию о досрочном освобождении и установившее запрет на возбуждение дел об условно-досрочном освобождении народными судами и революционными трибуналами;

- Уголовный кодекс СССР 1922 г., закрепивший норму об условно-досрочном освобождении для лиц, которым назначено лишение свободы или принудительные работы и которые отбыли не менее половины срока наказания;

- Уголовно-процессуальный кодекс СССР 1922 г., определивший возможность судов отказать в удовлетворении ходатайства об условно-досрочном освобождении от отбывания наказания;

- Уголовно-исправительный кодекс СССР 1924 г., наделивший, помимо судов, правом условно-досрочного освобождения распорядительные комиссии;

- Основные начала уголовного законодательства СССР и союзных республик 1924 г. в редакции 1927 г., расширившие основания применения условно-досрочного освобождения от отбывания наказания, помимо лишения свободы, принуди- 
тельных работ, и ссылки, а в последующем и к любой срочной мере наказания, а еще дальше, после изменений 1977 г., 1982 г., и с обязательным привлечением к труду такого осужденного;

- УК РСФСР 1926 г., также разрешавший условно-досрочное освобождение от отбывания наказания, по специальному указанию Особого совещания при НКВД СССР;

- Указ Президиума Верховного Совета СССР от 14 июля 1954 г., как и в дореволюционный этап и начальный этап развития советского уголовного законодательства, определивший право на условно-досрочное освобождение от отбывания наказания осужденным к отбыванию наказания в местах заключения, показавшим положительное отношение к труду при отбывании там наказания и отбывшими не менее 2/3 срока;

- Указ от 21 апреля 1955 г., разрешивший условнодосрочное освобождение и от дополнительного наказания;

- Закон от 11 июня 1969 г., запретивший применение условно-досрочного освобождения от отбывания наказания для определенного круга лиц, в том числе рецидивистов, государственных преступников.

С принятием нового уголовного кодекса России - Уголовного кодекса Российской Федерации (далее - УК РФ) 1996 г., вступившего в силу в 1997 г., развитие института условно-досрочного освобождения продолжилось, включая направление его совершенствования и модернизации.

В настоящее время институт УДО остается востребованным инструментом в исправлении осужденных, и реализации конституционно-правовых принципов гуманизма и справедливости и нормы о нем закреплены в главе 12 УК РФ, в частности, в ст. 79.

УДО по своей юридической природе является одним из видов освобождения от отбывания наказания, состоящем в досрочном освобождении осужденного от дальнейшего реального отбывания наказания при условии соблюдения во время неотбытой части наказания определенных требований, установленных законом, надлежащего исполнения возложенных на это время обязанностей, предусмотренных нормами уголовного законодательства и также несовершения в течении времени неотбытого уголовного наказания иных преступлений или административных правонарушений. Однако помимо понимания правовой природы УдО как одного из видов освобождения от наказания, выделяются в правовой литературе и другие научные концепции о правовой природе УДО. В частности, УДО трактуют как поощрительную меру, как одного из видов освобождения от дальнейшего отбывания наказания и как законный интерес.

В современный период сохраняется тенденция к снижению удовлетворенных ходатайств об условно-досрочном освобождении от отбывания наказания, связанная как с совершенствованием законодательства об условно-досрочном освобождении, в том числе относительно осуществления контроля за лицами, условно-досрочно освобожденными, так и с изменением в следствии гуманизации российской уголовно-правовой системы наказаний «качественного» состава осужденных.

Однако, несмотря на фактическое ужесточение законодательства об условно-досрочном освобождении, проблемы по применению данного уголовно-правового института остаются. В их числе проблемы, связанные с выработкой и нормативным закреплением четких правовых критериев определения степени исправления осужденного, по достижению которой может быть признано судом, что он не нуждается в полном отбывании уголовного наказания; проблемы применения этого института к осужденным, длительное время содержавшихся до вступления приговора суда в законную силу под стражей, к осужденным к пожизненному лишению свободы; проблемы обеспечения объективности в принятии решений об условно-досрочном освобождении. В связи с этим необходимо в п. 4.1. ст. 79 УК РФ внести изменения, касающиеся детализации в нем перечня критериев условно-досрочного освобождения от отбывания наказания для осужденных в зависимости от тяжести преступления и назначенного наказания, и установления требования о наличии не только соответствующего заключения администрации исправительного учреждения, но и заключений о рекомендации к условно-досрочному освобождению представителей Уполномоченного по правам человека в субъектах Российской Федерации, заключений общественных наблюдательных комиссий с предоставлением им функций общественного контроля исправительных учреждений.

\section{ЛИТЕРАТУРА}

1. Бабаян С.Л. Освобождение от отбывания наказания: проблемы и пути совершенствования // Уголовно-исполнительное право. - 2018. - Т. 13 (1-4). № 3. - C. 309-314.

2. Беляков А.В. История развития института условно-досрочного освобождения от отбывания // Вестник Самарского юридического института. - 2015. № 4 (18). - C. 125-130. 
3. Горшенин А.А. Условно-досрочное освобождение от отбывания наказания несовершеннолетних: Автореф. дисс. на соиск. уч. ст. канд. юрид. наук: 12.00.08. - Казань, 2006. -26 с.

4. Комментарий к Уголовному кодексу Российской Федерации (постатейный). Исправлен, дополнен, переработан / Под ред. д-ра юрид. наук, проф. А. И. Чучаева. - М.: КОНТРАКТ, 2013. - 672 с.

5. Обзор судебной практики условно-досрочного освобождения от отбывания наказания (утв. Президиумом Верховного Суда РФ 29 апреля 2014 г.) // Бюллетень Верховного Суда РФ. - 2014. - № 8.

6. Постановление Пленума Верховного Суда РФ от 21 апреля 2009 г. № 8 «0 судебной практике условно-досрочного освобождения от отбывания наказания, замены неотбытой части наказания более мягким видом наказания» (в ред. Постановлени Пленума Верховного Суда РФ от 17 ноября 2015 г. № 51 ) // Бюллютень Верховного Суда РФ. - 2009. - № 7; 2016. - № 1.

7. Рыбаков А.А. Контроль за лицами, условно-досрочно освобожденными от отбывания наказания: Дисс. на соиск. уч. ст. канд. юрид. наук: 12.00.08. Владимир, 2015. - 173 с.

8. Уголовный кодекс Российской Федерации от 13 июня 1996 г. № 63-Ф3 (в ред. Федерального закона от 27 декабря 2019 г. № 500-Ф3) // Собрание законодательства РФ. - 1996. - № 25. - Ст. 2954; Российская газета. - 2019. - 30 декабря. - № 295.

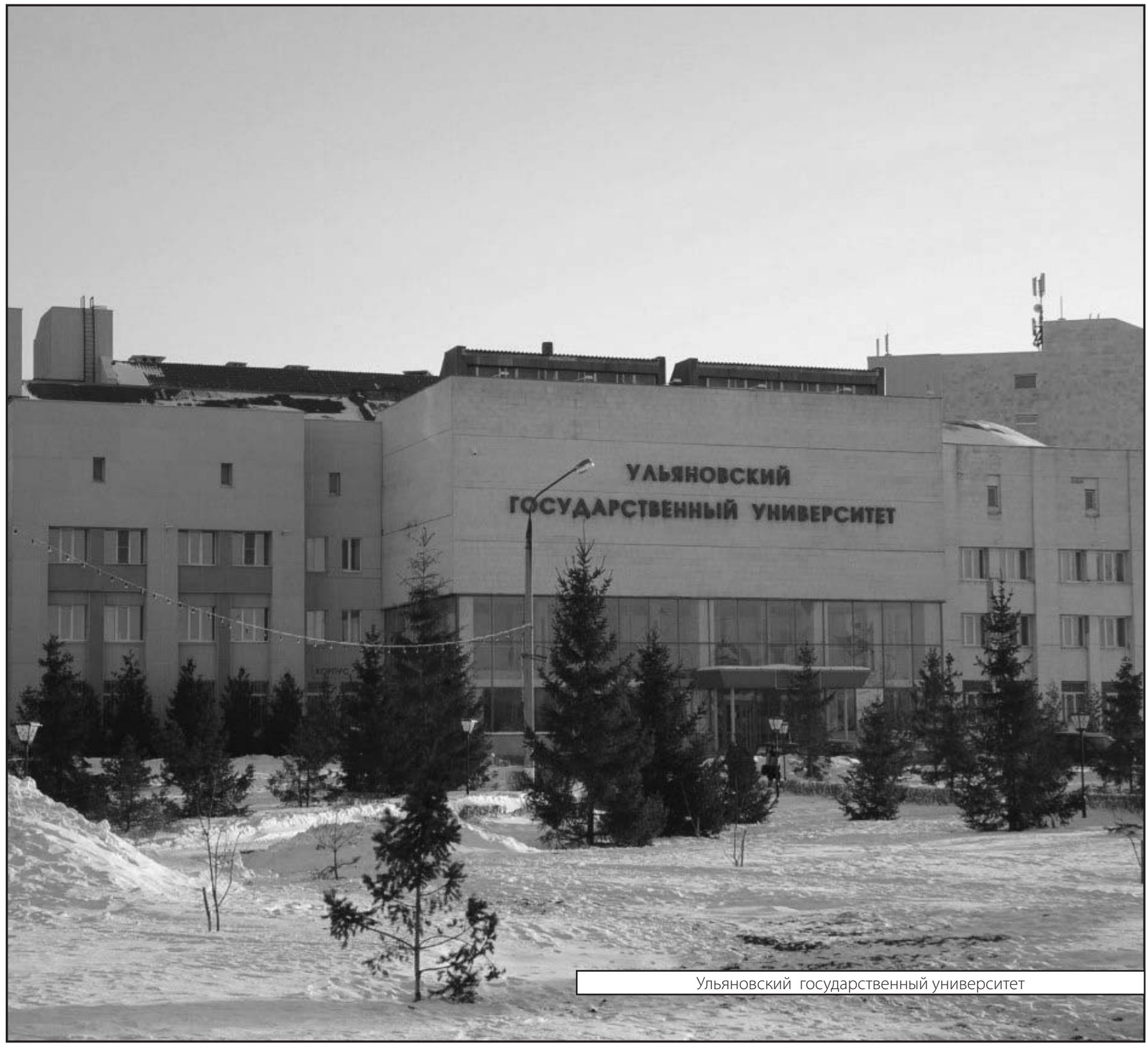

